\title{
THE BLOOD GROUPS AND HÆMOGLOBINS OF THE SIKHS
}

\author{
G. W. G. BIRD, ELIZABETH W. IKIN, H. LEHMANN and \\ A. E. MOURANT \\ Lister Institute, London, S.W. 1
}

Received 6.ii. $5^{6}$

BLOOD-GROUP studies show, beneath the diversity of the settled peoples of India, an underlying uniformity, whereas many of the aboriginal tribes differ from these people in a more marked and fundamental manner. The numerous and scattered references to these studies have been listed by Boyd (r939) and Mourant (r954) who have also collected most of the published data into tables.

The settled peoples show varying but always high frequencies of group $\mathrm{B}$, and rather high frequencies of $\mathrm{A}$. The aboriginal tribes may or may not show these features, and some show ABO frequencies which in different ways are near the extreme limits found among human populations. The only blood-group system other than the ABO, for which the data are adequate to show systematic differences within the Indian sub-continent, is the $\mathrm{Rh}$ system. With respect to the latter, most of the settled peoples so far sampled show frequencies closely similar to those of the Mediterranean peoples who have, however, very different $\mathrm{ABO}$ frequencies. There are usually 5 to Io per cent. of Rh-negatives (mostly cde/cde), with a very high frequency of genotypes containing $\mathrm{GDe}\left(\mathrm{R}_{1}\right)$, and with $\mathrm{cDE}\left(\mathrm{R}_{2}\right)$, present but less frequent than in northern Europe. The chromosome: $\operatorname{CDE}\left(\mathrm{R}_{\mathrm{z}}\right)$ is absent or very rare.

Many of the aboriginal tribes, on the other hand, are entirely lacking in Rh-negatives and among them $\mathrm{CDE}$ is not very rare. Some of these tribes, of a Veddoid type, and living in the Nilgiri Hills, have a moderately high frequency of the sickle-cell trait which appears to be absent from the settled peoples of the same region (Lehmann and Cutbush, 1952). The settled peoples in general are, however, far from being genetically uniform - they are apparently less so, for example, than the peoples of northern and central Europe. This is particularly shown in the study by Sanghvi and Khanolkar (1950-5I). of a number of different castes in Bombay. There is, therefore, still considerable scope for blood-group studies of different communities; especially if these tend to be exclusively endogamous. In order, however, to discover statistically significant differences between the communities, it will become necessary to test larger numbers of persons than have usually been examined in the past, and any considerable extension of the work must depend on the development of laboratory facilities and serum supplies in India.

In the present paper we describe an investigation which was in 
the first place intended to cover the $A_{1} A_{2} B O, M N S$ and $R h$ groups of the Sikhs. As the work proceeded the rapid progress of research on the abnormal hæmoglobins (one of which is responsible for sickling) made it desirable to look for those as well. All blood samples were

TABLE I

The $A_{1} A_{2} B O$ blood groups of 213 Sikhs

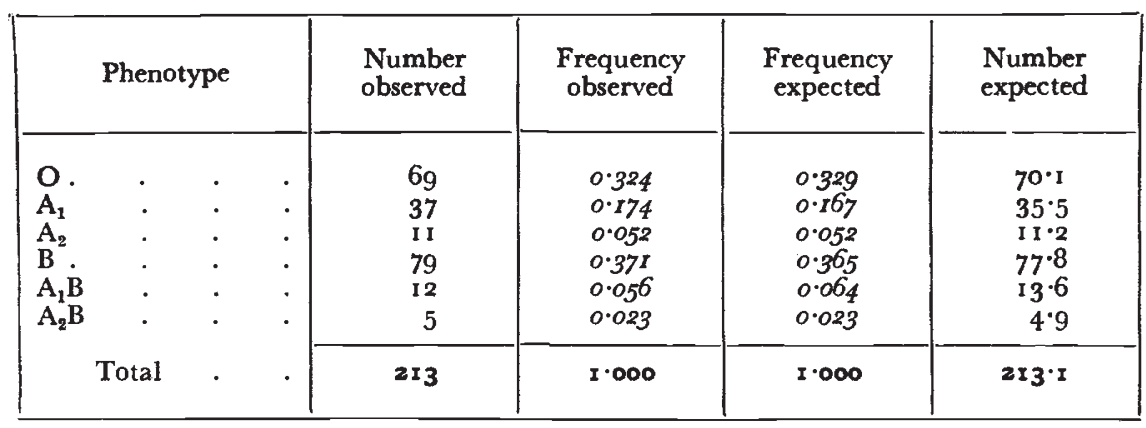

Gene frequencies

$$
\begin{array}{lccccc}
\mathbf{A}_{1} & \cdot & \cdot & \cdot & \cdot & 0.123 \\
\mathbf{A}_{2} & \cdot & \cdot & \cdot & \cdot & 0.044 \\
\mathbf{B} & \cdot & \cdot & \cdot & \cdot & 0.260 \\
\mathrm{O} & \cdot & \cdot & \cdot & \cdot & 0.573 \\
& \text { Total } & \cdot & \cdot & \mathbf{I} \cdot 000 \\
& & & &
\end{array}
$$

TABLE 2

The ABO blood groups of 600 Sikhs*

\begin{tabular}{|c|c|c|c|c|c|c|c|}
\hline \multicolumn{4}{|c|}{ Phenotype } & $\begin{array}{l}\text { Number } \\
\text { observed }\end{array}$ & $\begin{array}{l}\text { Frequency } \\
\text { observed }\end{array}$ & $\begin{array}{c}\text { Frequency } \\
\text { expected }\end{array}$ & $\begin{array}{l}\text { Number } \\
\text { expected }\end{array}$ \\
\hline \multirow[t]{2}{*}{$\begin{array}{l}\text { O. } \\
\text { A . } \\
\text { B : } \\
\text { AB }\end{array}$} & $\dot{.}$. & $\dot{.}$. & • & $\begin{array}{r}205 \\
152 \\
199 \\
44\end{array}$ & $\begin{array}{l}0.34^{2} \\
0.253 \\
0.332 \\
0.073\end{array}$ & $\begin{array}{l}0.349 \\
0.245 \\
0.324 \\
0.083\end{array}$ & $\begin{array}{r}209 \cdot 2 \\
\text { I } 47 \cdot 1 \\
\text { I } 94 \cdot 2 \\
49 \cdot 6\end{array}$ \\
\hline & Total & . & • & 600 & $1 \cdot 000$ & $I \cdot 001$ & $600 \cdot I$ \\
\hline
\end{tabular}

* The $2{ }_{3}$ listed in table $I$ are not included in these 600 .

$$
\begin{array}{cccccc}
\multicolumn{7}{c}{\text { Gene frequencies }} \\
\text { A } & . & \cdot & \cdot & \cdot & 0.180 \\
\text { B } & \cdot & \cdot & \cdot & \cdot & 0.229 \\
\text { O } & \cdot & \cdot & \cdot & \cdot & 0.590 \\
& \text { Total } & . & . & . & 0.999
\end{array}
$$

tested with the sera anti-A, -B, -C, -D, -E, -c, -M, -N, -S. Samples positive with anti-A were tested with anti- $A_{1}$, and those positive with anti-E, with anti-e. Those which were negative with a saline anti-D were tested by means of the indirect anti-human-globulin technique 
with several incomplete anti-D sera in order to detect the antigen $D^{n}$ if present. The anti-C serum used had, as usual, the specificity anti-C+anti-Cw. Samples positive with this serum among the last Iog examined were further tested with pure anti-Cw. The same Iog samples were also tested with anti-Henshaw (all with negative results), and the hæmoglobin from them was tested at St Bartholomew's Hospital by means of paper electrophoresis. A further I 70 specimens were tested electrophoretically but were not examined for blood groups. Samples from another 6oo individuals were tested at Poona with anti-A and anti-B. The results of our tests are shown in tables 1-5. Gene frequency calculations were performed by the methods described by Mourant (1954).

The frequencies of the $A, B$ and $O$ genes fall well within the range

TABLE 3

The MNS blood groups of the Sikhs

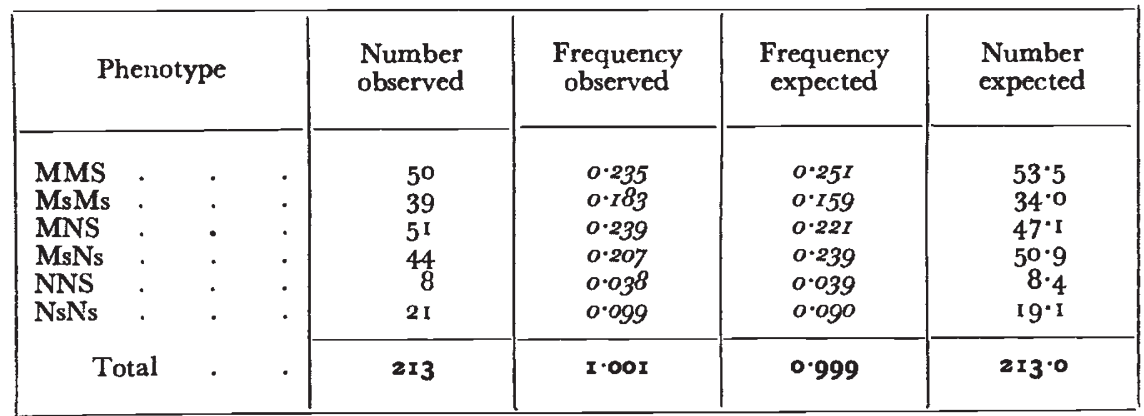

Chromosome frequencies

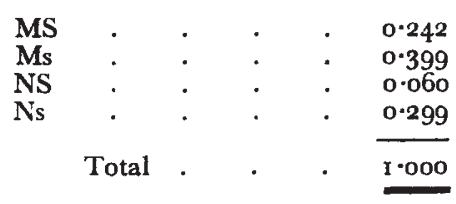

of frequencies characteristic of north Indian populations. The $\mathrm{A}_{2}$ gene is present; its frequency appears higher than in most north Indian populations, but the difference is not statistically significant. The MNS frequencies also are similar to the values previously found for the region but the frequency of the Ms chromosome is among the higher reported values.

The $\mathrm{Rh}$ frequencies also are fairly typical of the north Indian region, but with the frequency of chromosomes $\mathrm{CDe}$ and $\mathrm{CDE}$ among the higher of the values previously reported, and that of cde among the lower. The $\mathrm{C}^{\mathrm{w}}$ gene had previously been found in the Indian sub-continent (in Pakistan) (Chaudhri et al., 1952), only in the rare combination $\mathrm{C}^{\mathrm{w}} \mathrm{de}$. In the present series, in the absence of the genotype $\mathrm{C}^{\mathrm{w}} \mathrm{de} / \mathrm{cde}$, it is presumed that, as in Europe, $\mathrm{C}^{\mathrm{w}}$ occurs in the combination $\mathrm{G}$ De. The typically African cDe chromosome 
TABLE 4

The $R h$ blood groups of the Sikhs

\begin{tabular}{|c|c|c|c|c|}
\hline Phenotype & $\begin{array}{l}\text { Number } \\
\text { observed }\end{array}$ & $\begin{array}{l}\text { Frequency } \\
\text { observed }\end{array}$ & $\begin{array}{l}\text { Frequency } \\
\text { expected }\end{array}$ & $\begin{array}{l}\text { Number } \\
\text { expected }\end{array}$ \\
\hline 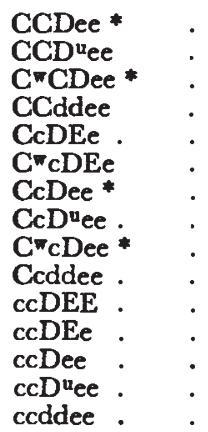 & $\begin{array}{l}91 \cdot 636 \\
1 \\
4 \cdot 364 \\
0 \\
30 \\
0 \\
57 \cdot 156 \\
0 \\
1 \cdot 844 \\
1 \\
5 \\
9 \\
3 \\
1 \\
8\end{array}$ & $\begin{array}{l}0.430 \\
0.005 \\
0.020 \\
\ldots \\
0.141 \\
\ldots . \\
0.268 \\
\ldots \\
0.009 \\
0.005 \\
0.023 \\
0.042 \\
0.014 \\
0.005 \\
0.038\end{array}$ & $\begin{array}{l}0.423 \\
0.001 \\
0.019 \\
0.000 \\
0 \cdot 154 \\
0.003 \\
0.266 \\
0.010 \\
0.006 \\
0.005 \\
0.014 \\
0.051 \\
0.012 \\
0.004 \\
0.031\end{array}$ & $\begin{array}{r}90 \cdot 2 \\
0 \cdot 3 \\
4 \cdot 1 \\
0 \cdot 0 \\
32 \cdot 7 \\
0 \cdot 7 \\
56 \cdot 6 \\
2 \cdot 2 \\
1 \cdot 3 \\
1 \cdot 0 \\
3 \cdot 0 \\
10 \cdot 8 \\
2.5 \\
0 \cdot 8 \\
6.6\end{array}$ \\
\hline Total & 213.000 & I.000 & 0.999 & $212 \cdot 8$ \\
\hline
\end{tabular}

* For the first 104 specimens tested, no distinction was made between $\mathbf{C}$ and $\mathbf{C}$. I It has therefore been assumed that the phenotypes CCDee and CcDee among these specimens included $C^{\prime}$ CDee and $C^{*} \mathrm{cDee}$ respectively in the same proportions as for the 109 specimens tested subsequently.

Chromosome frequencies

\begin{tabular}{|c|c|c|c|c|c|}
\hline \multirow{8}{*}{$\begin{array}{l}\text { CDe } \\
C^{\mp} D e \\
C D^{u} e \\
\text { Cde } \\
\text { cDE } \\
\text { cDe } \\
\text { cDue }^{\text {ue }} \\
\text { cde }\end{array}$} & . & • & . & . & 0.612 \\
\hline & . & . & . & . & 0.015 \\
\hline & . & . & . & . & 0.027 \\
\hline & . & . & . & . & 0.013 \\
\hline & . & . & . & . & 0.118 \\
\hline & . & . & . & . & 0.029 \\
\hline & . & . & . & • & 0.011 \\
\hline & . & . & - & • & 0.176 \\
\hline & Total & & • & ${ }^{\circ}$ & $\mathrm{I} \cdot 00 \mathrm{I}$ \\
\hline
\end{tabular}

TABLE 5

The hamoglobins of the Sikhs

\begin{tabular}{|c|c|c|c|c|c|c|c|}
\hline \multicolumn{4}{|c|}{ Genotypes } & $\begin{array}{l}\text { Numbers } \\
\text { observed }\end{array}$ & $\begin{array}{c}\text { Frequencies } \\
\text { observed }\end{array}$ & $\begin{array}{c}\text { Frequencies } \\
\text { expected }\end{array}$ & $\begin{array}{l}\text { Numbers } \\
\text { expected }\end{array}$ \\
\hline \multirow[t]{2}{*}{$\begin{array}{l}\text { AA } \\
\text { AD } \\
\text { DD }\end{array}$} & $\dot{.}$ & $\dot{.}$ & $\dot{.}$ & $\begin{array}{r}274 \\
4 \\
1\end{array}$ & $\begin{array}{l}0.9821 \\
0.0143 \\
0.0036\end{array}$ & $\begin{array}{l}0.9786 \\
0.0213 \\
0.0001\end{array}$ & $\begin{array}{r}273.03 \\
5.94 \\
0.03\end{array}$ \\
\hline & Total & . & . & 279 & $I \cdot 0000$ & $I \cdot 0000$ & $279 \cdot 00$ \\
\hline
\end{tabular}

Gene frequencies

$\begin{array}{cccccc}\text { A } & \cdot & \cdot & \cdot & \cdot & 0.9892 \\ \text { D } & \cdot & \cdot & \cdot & \cdot & 0.0108 \\ & \text { Total } & \cdot & \cdot & \cdot & 1 \cdot 0000\end{array}$


has a frequency below that usually found in the Mediterranean area, or even in northern Europe. The $\mathrm{cD}^{\mathrm{u}} \mathrm{e}$ chromosome, recognisable in one individual, is almost completely absent in northern Europe but is found, with very much higher frequencies than in the present case, in certain Mediterranean and African populations.

Five persons out of 279 were found to carry hæmoglobin D. Four of these had hæmoglobins A and D : one had only D and is presumed to be homozygous for the corresponding gene, but this conclusion must be accepted with reservations until confirmed by family investigations. It is clear, however, that hæmoglobin D, though not common, is something more than a sporadic mutant as had been suspected when it had been found only in one Sikh (Bird, Lehmann and Mourant, 1955) and in two families of European ancestry. At the same time as the tests on the Sikhs, specimens from I3 Punjabi Hindus were tested, with the discovery of one individual heterozygous for hæmoglobins $\mathrm{A}$ and $\mathrm{D}$. The production of hæmoglobin D thus seems to be essentially a Caucasoid character. Hæmoglobin S, typical of Africans and of Indian and Arabian Veddoids, was not found, nor was hæmoglobin E, typical of S.E. Asia but penetrating into India.

Acknowledgments.-We should like to thank Dr Ada C. Kopeć for performing the calculations, and Miss P. J. Brooks and Miss K. E. Garner for technical assistance.

Note.-The present addresses of the authors are :-G. W. G. Bird : Armed Forces Medical College, Poona I, India. H. Lehmann: St Bartholomew's Hospital, London E.I.

\section{REFERENCES}

BIRD, G. W. G., LEHMANN, H., AND MOURANT, A. E. 1955. A third example of hæmoglobin D. Trans. R. Soc. trop. Med. Hyg., 49, 399-400.

BOYD, w. C. 1939. Blood groups, Tabul. biol., 17, part 2, I1 3-240.

CHAUDHRI, I. M., IKIN, ELIZABETH W., MOURANT, A. E., AND WALBY, JEAN A. E. 1952.

The blood groups of the people of north-east Pakistan. Man, 52, 168-169.

LehmanN, H., AND CutBush, MARIE. 1952. Sickle-cell trait in Southern India. Brit. med. F., I, 404 .

MOURANT, A. E. 1954. The Distribution of the Human Blood Groups. Oxford.

SANGHVI, L. D., AND KHANOLKaR, v. R. 1950-51. Data relating to seven genetical characters in six endogamous groups in Bombay. Ann. Eugen. London, 15, $52-64$. 